\title{
STATUS OF AUSTROPOTAMOBIUS PALLIPES COMPLEX IN THE WATERCOURSES OF THE ALESSANDRIA PROVINCE (N-W ITALY)
}

\author{
P.A. NARDI (1), F. BERNINI (1), T. BO (2), A. BONARDI (1), G. FEA (1), D. GHIA (1),
} A. NEGRI (2), E. RAZZETTI (3), S. ROSSI (1), M. SPAIRANI (1)

(1) Dipartimento di Biologia Animale, Università degli Studi di Pavia, P.zza Botta 9, 27100 Pavia, Italy.

E-Mail: acquint@unipv.it

(2) Dipartimento di Scienze dell'Ambiente e della Vita, Università del Piemonte Orientale, Via Bellini 25/G, 15100 Alessandria, Italy.

(3) Centro Interdipartimentale Servizi Musei Universitari, Università degli Studi di Pavia, P.zza Botta 9, 27100 Pavia, Italy.

Reçu le 5 novembre 2004

Accepté le 25 janvier 2005

Received November 5, 2004

Accepted January 25, 2005

\begin{abstract}
Information was gathered on the distribution of white-clawed crayfish Austropotamobius pallipes complex in the watercourses of the Alessandria province (NW Italy), on the biological and ecological preferences of the species, and on the features of the biotopes in which it is found. A total of 409 sites on 361 watercourses connected to the main sub-basins of the Po River were analysed, with data gathered during the field research phase, conducted for three consecutive summers from 2002 through 2004. Thirteen percent of the sites investigated were found to currently house crayfish populations. The persistence in time of superficial water and natural morphology of the watercourse were found to be the chief requirements for the presence of crayfish. Data on land use, human density and other factors which potentially limit the survival of crayfish populations were also analysed.
\end{abstract}

Key-words: Austropotamobius pallipes complex, freshwater crayfish, bio-ecological characteristics.

\section{STATUT DU COMPLEXE D'ESPACE D'AUSTROPOTAMOBIUS PALLIPES DANS LES COURS D'EAU DE LA PROVINCE D'ALESSANDRIA (ITALIE NORD-OCCIDENTALE)}

\section{RÉSUMÉ}

Le projet de recherche a prévu la récolte d'informations sur la répartition du complexe d'espèce Austropotamobius pallipes dans les réseaux hydrographiques de la province d'Alessandria (Italie nord-occidental), sur les caractères bio-écologiques de l'espèce et sur les caractéristiques des milieux où elle a été trouvée. Les prospections de terrain ont été faites durant trois étés consécutifs de la période 2002-2004 et ont permis d'analyser 409 sites sur 361 cours d'eau, appartenant aux principaux sous-bassins du fleuve Pô. Des populations d'écrevisses n'ont été trouvées que dans $13 \%$ des sites prospectés. La persistance temporelle des débits hydriques superficiels et la morphologie naturelle constituent la condition essentielle pour la présence des écrevisses. En outre, les données 
ont été analysées par rapport au mode d'utilisation du sol, à la densité démographique et à d'autres aspects qui limitent, potentiellement, la survie des populations astacicoles.

Mots-clés : Austropotamobius pallipes complexe, écrevisse, caractéristiques bioécologiques.

\section{INTRODUCTION}

Austropotamobius, the only autochthonous genus of crayfish found in Italian freshwater courses, is present on the Italian mainland but not on the surrounding islands (GHERARDI et al., 1999). Although it is known to be widely distributed throughout the peninsula, information on its range and density is very general and out of date. Habitat Directive 92/43/CEE, received in Italian law (DPR 357/97 and DPR 120/2003), qualifies A. pallipes as a species of European community interest for which conservation areas must be set aside (Annex II) and which is subject to periodic sampling for the purpose of population management (Annex V).

Some regional administrations have approved even more stringent legislation. In Piedmont, for example, the capture, transport, trade and keeping in captivity of animals for sale are forbidden except in areas where fishing and sale are permitted and water bodies are repopulated regularly from breeding stock (art. 29, L.R. n. 32 of 2/11/1982). A. pallipes is also classified as vulnerable by the IUCN (2000).

The purpose of our research was to obtain a clear picture of the distribution and of the ecological and biological preferences of freshwater crayfish in the Alessandria province (in the south-east of the region of Piedmont) in order to be able to apply commmunitary conservation law.

Recent research has revealed the presence of two distinct taxonomic entities in Italian fresh waters: $A$. pallipes, found in northwestern Italy and $A$. italicus in northeastern and peninsular Italy (NASCETTI et al., 1997; SANTUCCI et al., 1997; GRANDJEAN et al., 2000; LARGIADÈR et al., 2000; ZACCARA et al., 2004). The results of genetic characterization of all the crayfish populations found in the study area are presently being analysed. Preliminary results of comparison of 16SmtDNA gene sequences confirm that the two species overlap in the province of Alessandria and appear to be sympatric in at least two of the brooks examined (NEGRI et al., 2003). As not enough is yet known about the two species to distinguish them morphologically, the results of this study refer only to the Austropotamobius pallipes complex.

\section{MATERIALS AND METHODS}

The study area covered the whole of the Alessandria province in the northwestern Italy, which has a continental climate. The province has a diversified orographic structure with $53 \%$ of its $3,560 \mathrm{~km}^{2}$ surface area consisting of hills, $12 \%$ of mountains and $35 \%$ of lowlands. The mountains, which reach a maximum elevation of $1,700 \mathrm{~m}$, are situated in the south-easternmost part of the province. Alessandria is crossed by $2,800 \mathrm{~km}$ of watercourses, which make up a dense hydrographic network characterized by different types of water bodies (rivers, streams, brooks, resurgences and artificial canals). It has a human population of about 450,000 living in 190 municipalities of which 116 have fewer than 1,000 inhabitants and of which only 10 have more than 5,000 inhabitants. The average population density is 123 inhabitants $/ \mathrm{km}^{2}$ (MALACARNE, CUCCO and BOANO, 1999).

Five different land use categories were identified from the territorial map supplied by the administration of the Provincia di Alessandria. In terms of total surface area and in 
increasing order of human impact, these account for: woodlands, 25\%; grasslands, 33\%; vineyards/orchards, $21 \%$; sown fields, $17 \%$; urban areas, $4 \%$.

A preliminary picture of the distribution of Austropotamobius was put together from bibliographic research, evaluation of collections in some natural science museums (Milan, Pavia, Novara, Bra and Stazzano), and interviews with fishermen and wildlife conservation workers. For three consecutive summers from 2002 through 2004, field investigations were carried out on all the watercourses in Alessandria. Survey sites were identified on maps IGM 1: 25,000 and CTR 1: 10,000 (supplied by the Provincia di Alessandria), with no water body being excluded a priori. On large watercourses, several 100-500 m stretches were investigated.

Crayfish were searched for mainly by hand in all possible refuges: stones and leaf litter on the bottom of watercourses, holes along the riverbank, and abandoned trash. A fine mesh dip net was used to capture specimens in aquatic vegetation. Their presence was also detected by means of moults. Where watercourses were too turbid or large to capture crayfish by hand, traps were placed for sampling purposes for at least one night (MORIARTY, 1972; BROWN and BREWIS, 1978).

Sites were described by compiling a table of characteristics (see Table I) based on rapid bioassessment protocols (BARBOUR et al., 2002) that includes parameters for the biological and ecological requirements of crayfish (DAGUERRE DE HUREAUX and ROQUEPLO, 1981; SMITH et al., 1996) and items referring to water quality and site resilience (GHETTI, 1997; ANPA, 2000; FONDAZIONE LOMBARDIA PER L'AMBIENTE, 2002). Not all of these parameters will be shown in this paper.

\section{Table I}

\section{Variables used in the survey.}

\section{Tableau I}

Variables utilisées dans l'étude.

\section{General descriptors}

- date of survey, weather conditions, basin, watercourse, name of site surveyed, altitude (m a.s.I.), air temperature, GPS coordinates, length of surveyed stretch, search effort (time per number of operators), previous reports

\section{Population descriptors}

- presence/absence of freshwater crayfish or moults; number, sex and size of found freshwater crayfish

\section{Instream habitat descriptors}

- width of submerged river bed $(\mathrm{m})$, medium and maximum water depth (cm), speed of water flow (6 classes), variety of river course (4 classes), type of main substrate (6 granulometric classes), availability of shelters (5 classes of abundance), presence of aquatic macrophytes (6 classes of abundance), periphyton (6 classes of abundance)

\section{Riparian habitat descriptors (4 quality classes, for each bank)}

- bank structure and erosion; riparian vegetation type, width and continuity, channel shading (6 classes)

Water quality

- total hardness $\left(\mathrm{mg} / \mathrm{l} \mathrm{CaCO}_{3}\right), \mathrm{pH}$, conductivity $\left(\mu \mathrm{S} / \mathrm{cm}\right.$ at $\left.25^{\circ} \mathrm{C}\right), \mathrm{O}_{2}$ dissolved $(\mathrm{mg} / \mathrm{l})$ and $\mathrm{O}_{2} \%$, temperature $\left({ }^{\circ} \mathrm{C}\right)$, community state of aquatic macroinvertebrates (5 EBI classes) 
The status of aquatic macroinvertebrate communities was evaluated according to the EBI protocol (GHETTI, 1997) and an index of 1-5 was used to indicate quality, from 1 (unaltered macrobenthic community) to 5 (completely altered macrobenthic community).

Urbanization was expressed as the ratio of inhabitants in the river basin to length of the watercourse from the source to the first sampling point where crayfish were found.

Comparison of environmental parameters in sites where crayfish were found vs. those where crayfish were not found was conducted by means of the Mann-Whitney $U$ test; the Chi-squared test and Spearman's correlation on the SPSS 11.5 package.

\section{RESULTS}

Four hundred and nine sites on 361 watercourses were investigated. Only in 235 $(57.5 \%)$ watercourses was there perennial superficial water, either flowing or in the form of isolated pools. Austropotamobius pallipes complex was found in 53 of these (Figure 1). No specimens of allochthonous crayfish species were found. Table II shows the number of sites investigated, water conditions and the number of sites where crayfish were found in each river basin.

Eighteen reports of crayfish sightings in the Alessandria province were found in the preliminary overview of existing data. Of these only the one for the Piota Stream in the basin of the Orba Stream (SPANO and REMAGGI, 1974) was confirmed in the present study. No evidence of crayfish was found either in the main watercourse or in the tributaries to support more recent reports for the basin of the Curone Stream (FERRARI, 1981).

Crayfish were detected at altitude of 100 to $450 \mathrm{~m}$ a.s.I. with a majority of sightings (83\%) taking place at $150-350 \mathrm{~m}$ in the low and medium hills of the Apennine area (Figure 2). In particular, sites with $A$. pallipes complex are more frequent than sites without

\section{Table II}

Number of sites surveyed per river basin, showing the number of sites where water was present and the number of sites where $A$. pallipes complex was found. Percentages in round brackets are of the number of sites surveyed per river basin; percentages in square brackets are of the number of sites where water was present per river basin.

\section{Tableau II}

Répartition des sites avec présence d'eau et des sites avec $A$. pallipes dans le réseau hydrographique de la province d'Alessandria. Entre parenthèses: pourcentages sur le total des sites étudiés; entre crochets: pourcentages calculés sur le total des sites avec eau, pour chaque bassin.

\begin{tabular}{|l|c|c|c|}
\hline River basin & Sites surveyed & Water present & A. pallipes present \\
\hline Belbo & 6 & $2(33.3 \%)$ & 0 \\
\hline Bormida - B. Spigno & 107 & $47(43.9 \%)$ & $6[12.8 \%]$ \\
\hline Curone & 25 & $14(56.0 \%)$ & 0 \\
\hline Orba & 107 & $80(74.8 \%)$ & $29[36.2 \%]$ \\
\hline Po & 64 & $35(54.7 \%)$ & $5[14.3 \%]$ \\
\hline Scrivia & 63 & $42(66.7 \%)$ & $11[26.2 \%]$ \\
\hline Tanaro & 37 & $15(40.5 \%)$ & $2[13.3 \%]$ \\
\hline & $\mathbf{4 0 9}$ & $\mathbf{2 3 5} \mathbf{( 5 7 . 5 \% )}$ & $\mathbf{5 3}[\mathbf{2 2 . 6 \%}]$ \\
\hline
\end{tabular}



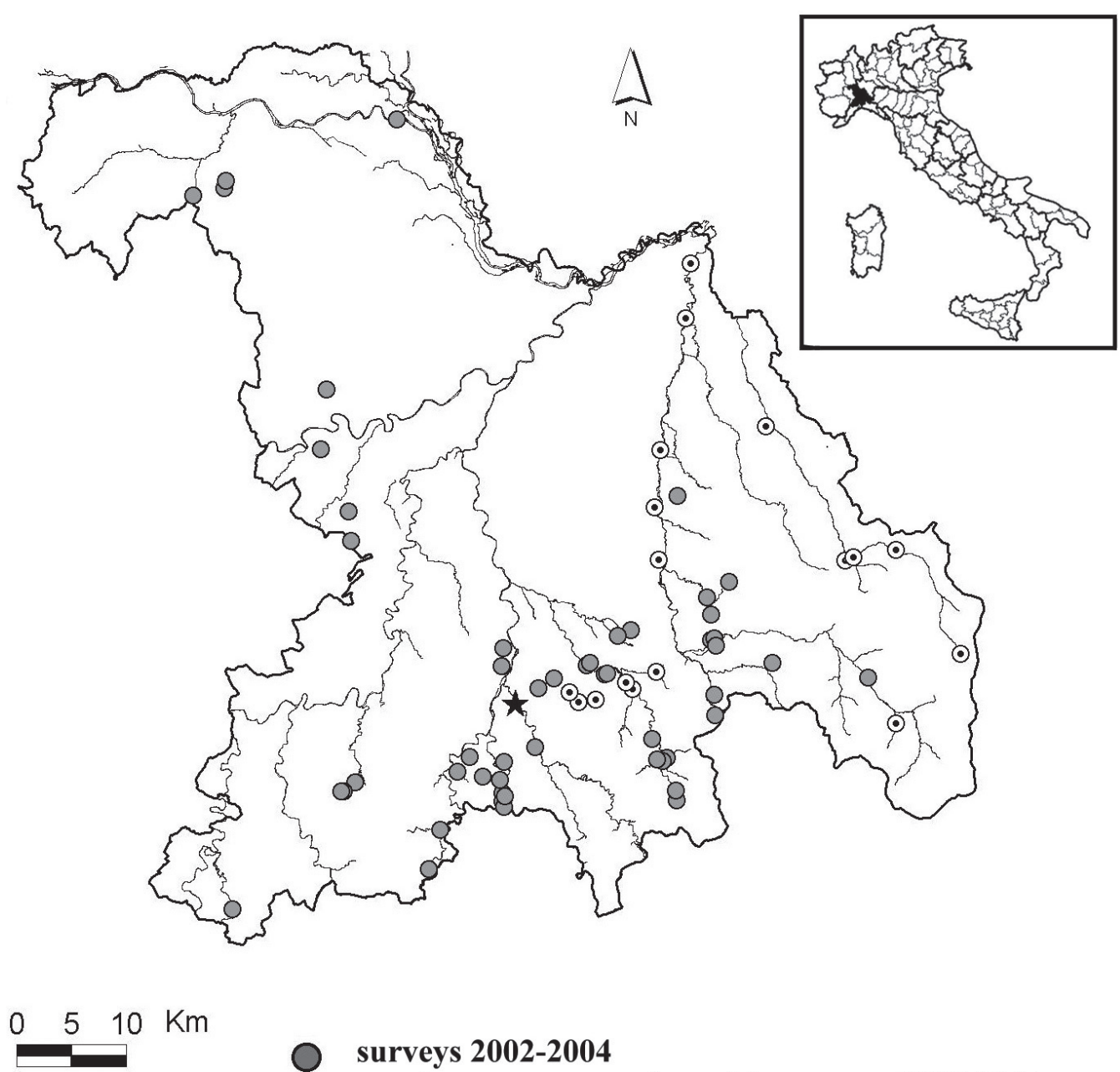

\author{
surveys 2002-2004 \\ $\star$ previous reports confirmed in surveys 2002-2004 \\ ○ previous reports unconfirmed
}

Figure 1

Distribution of $A$. pallipes complex populations in the province of Alessandria.

\title{
Figure 1
}

Distribution des populations d'A. pallipes complexe dans la province d'Alessandria.

crayfish at 250-350 m, and less frequent at the lowest and highest elevations (Pearson $\left.\chi^{2}=15.565 ; \mathrm{df}=4 ; p=0,004\right)$.

Water temperatures of $10.6-33^{\circ} \mathrm{C}$ were found at sites where water was present, with the highest values being measured in the basin of the Bormida - B. Spigno Stream. At sites where crayfish were found, water temperatures were mostly below $21^{\circ} \mathrm{C}(84.3 \%$ of sites) with the highest temperature of $26^{\circ} \mathrm{C}$ being measured in the Piota Stream (basin of the Orba Stream). Ranges of physical and chemical water parameters for the sites where crayfish were found are shown in Table III and in Figure 3.

Most crayfish populations $(42 / 53=79 \%)$ were found in sites where urbanization is below 100 inhabitants $/ \mathrm{km}$, with 36 sites lying in river basins where urbanization was 


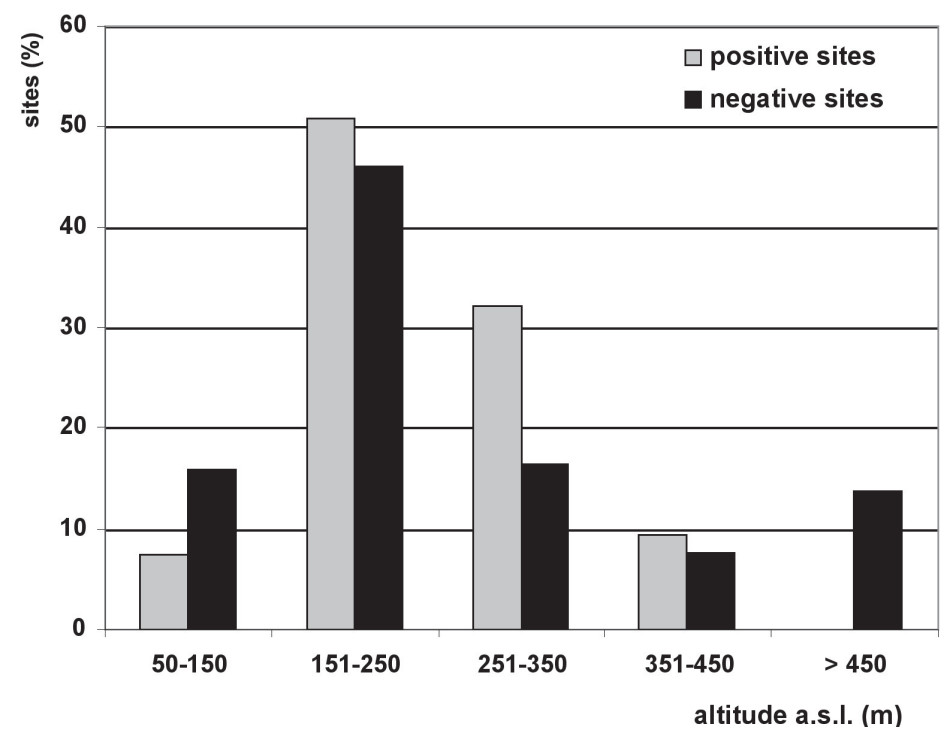

Figure 2

Presence and absence of $A$. pallipes complex according to altitude interval.

\section{Figure 2}

Répartition des sites étudiés dans les différentes classes altitudinales.
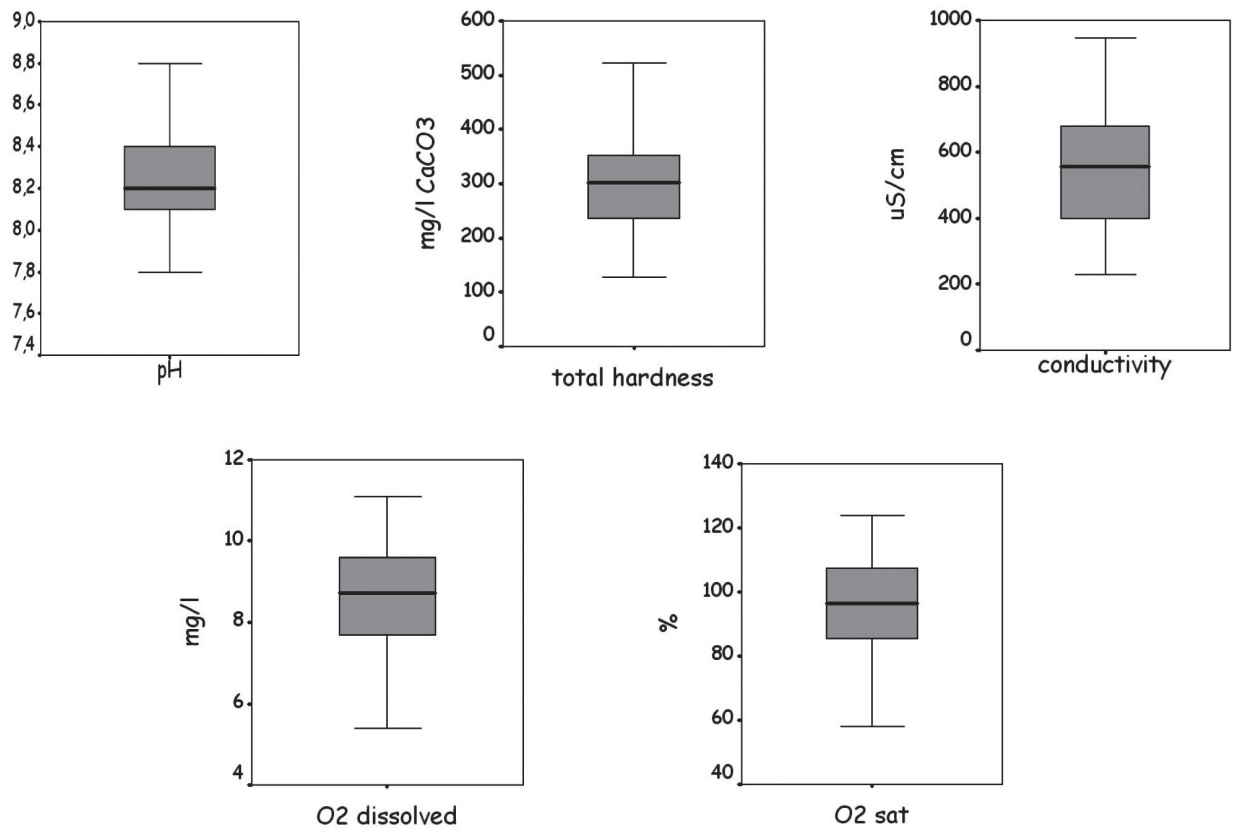

Figure 3

Boxplots of values of chemico-physical parameters measured on the sites with crayfish.

Figure 3

Boîtes à moustaches des valeurs des paramètres chimico-physiques mesurés dans les sites avec écrevisses. 


\section{Table III}

Values of chemical and physical parameters in sites where A. pallipes complex was found.

Tableau III

Valeurs des paramètres chimico-physiques relevés dans les sites avec écrevisses.

\begin{tabular}{|l|c|c|c|}
\hline Parameter & N & Mean & Range \\
\hline Water temperature $\left({ }^{\circ} \mathrm{C}\right)$ & 50 & & $11-26$ \\
\hline $\mathrm{pH}$ & 48 & 8.22 & $7.6-8.8$ \\
\hline Total hardness $\left(\mathrm{mg} / / \mathrm{CaCO}_{3}\right)$ & 50 & 301.6 & $127-545$ \\
\hline Conductivity $\left(\mu \mathrm{S} / \mathrm{cm}\right.$ at $\left.25^{\circ} \mathrm{C}\right)$ & 48 & 540.8 & $197-945$ \\
\hline $\mathrm{O}_{2}$ dissolved $(\mathrm{mg} / \mathrm{l})$ & 48 & 8.56 & $4.5-15.7$ \\
\hline $\mathrm{O}_{2}$ sat $(\%)$ & 48 & 96.0 & $47-170$ \\
\hline
\end{tabular}

0 inhabitants $/ \mathrm{km}$. Only one site, at 1,366 inhabitants $/ \mathrm{km}$, had an urbanization ratio above 600 inhabitants/km (see Figure 4).

Results of the Mann-Whitney $U$ test of environmental parameters for sites where A. pallipes complex were found $v s$. sites where they were not found are reported in Table IV. Only factors for which the difference was statistically significant or nearly significant are shown. Crayfish were found to be significantly more frequent in unchannelled stretches of watercourses which offer abundant shelters, and are characterized by a coarse granulometry bottom substrate and wide diversification of microhabitats (Figure 5).

It was not possible to apply the EBI protocol at 79 sites where the superficial water flow was fragmentised into isolated pools; or where flow velocity was almost 0.

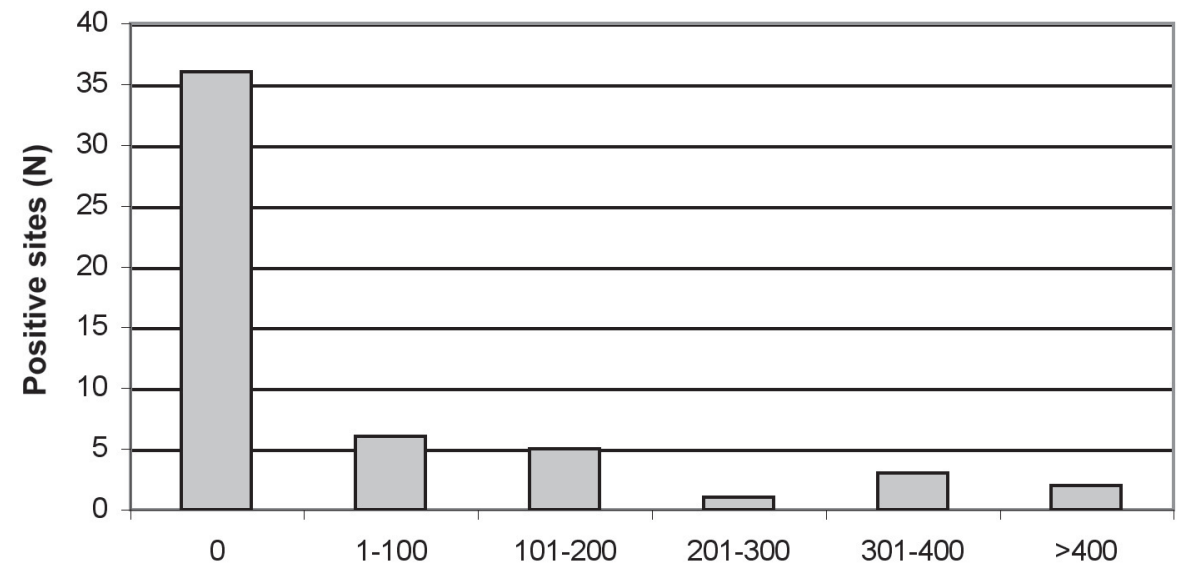

number of basin inhabitants / $\mathrm{km}$ of watercourse

Figure 4

Level of urbanization in sites where $A$. pallipes complex was found.

Figure 4

Niveau d'urbanisation des sites avec écrevisses. 
Table IV

Comparison of environmental characteristics in sites with $A$. pallipes complex vs. sites without $A$. pallipes complex (Mann-Whitney U test).

\section{Tableau IV}

Comparaison de quelques caractéristiques environnementales des sites avec ou sans écrevisses (test U de Mann-Whitney).

\begin{tabular}{|l|c|c|c|}
\hline Variable & $\mathbf{Z}$ & $\mathbf{n}$ tot & $\boldsymbol{p}$ \\
\hline Predominant granulometric class & -3.260 & 170 & $0.001^{\star \star}$ \\
\hline Abundance of shelters & -3.188 & 170 & $0.001^{\text {** }}$ \\
\hline E.B.I. class & -3.159 & 127 & $0.002^{\text {** }}$ \\
\hline Variety of river course & -2.462 & 170 & $0.014^{\star}$ \\
\hline Land use category & -1.876 & 409 & 0.061 \\
\hline
\end{tabular}

Nevertheless, crayfish were more frequent where the biological quality of the water was the best (Figure 6).

Comparing condition of water courses vs. land use (Figure 7) for all the sites (409), persistence of superficial water flow and the presence of isolated pools of water were found to be significantly more frequent in the most natural areas (woodlands and grasslands); whereas drying up of the water course was more frequent in agricultural and urban areas (Mann-Whitney $U$ Test: $Z=-3.41 ; p=0.001$ ).

Figure 8 shows that the latter two land uses corresponded with a significant decline in the biological quality of the water, which was the best in areas where human impact is the lowest i.e. woodlands and grasslands (Spearman correlation: $\rho=0.56$; $\mathrm{n}=127 ; p=0.001)$. Most sites $(77 \%)$ with crayfish populations are found in wooded areas (18 findings) and grassland (23 findings).

\section{DISCUSSION}

This comprehensive survey of the $A$. pallipes complex throughout the hydrographic system of the Alessandria province has substantially increased our knowledge of the distribution of this notoriously elusive species, which has been of little interest to man in recent years.

Although crayfish populations have been found at elevations of $600-1,000 \mathrm{~m}$ a.s.l. (FÜREDER et al., 2003), those investigated in the present study in the province of Alessandria were found at lower elevations in the low-medium hills of the Apennines where temperatures are more consistent with the known ecological and biological needs of the species. TACHET (2002) describes A. pallipes as a stenothermic psychrophile with a preference for temperatures below $15^{\circ} \mathrm{C}$ and according to MANCINI (1986), can tolerate $25^{\circ} \mathrm{C}$ only for brief lapses of time. However, thirty-two percent of the crayfish populations examined in this study inhabit sites where the summer water temperature is between 21 and $25^{\circ} \mathrm{C}$, with $26^{\circ} \mathrm{C}$ being recorded at one site. ALONSO (2001) reported average annual temperatures at sites inhabited by crayfish of 8.8 to $11.4^{\circ} \mathrm{C}$, with extremes of 0.6 and $24^{\circ} \mathrm{C}$. These findings suggest less strict stenothermy than was thought and a capacity to tolerate summer temperatures that stray widely from optimal values.

The data gathered for other parameters also yield values outside of some ranges found in the literature: the average water conductivity of $600-945 \mu \mathrm{S} / \mathrm{cm}$ found in $34 \%$ of 

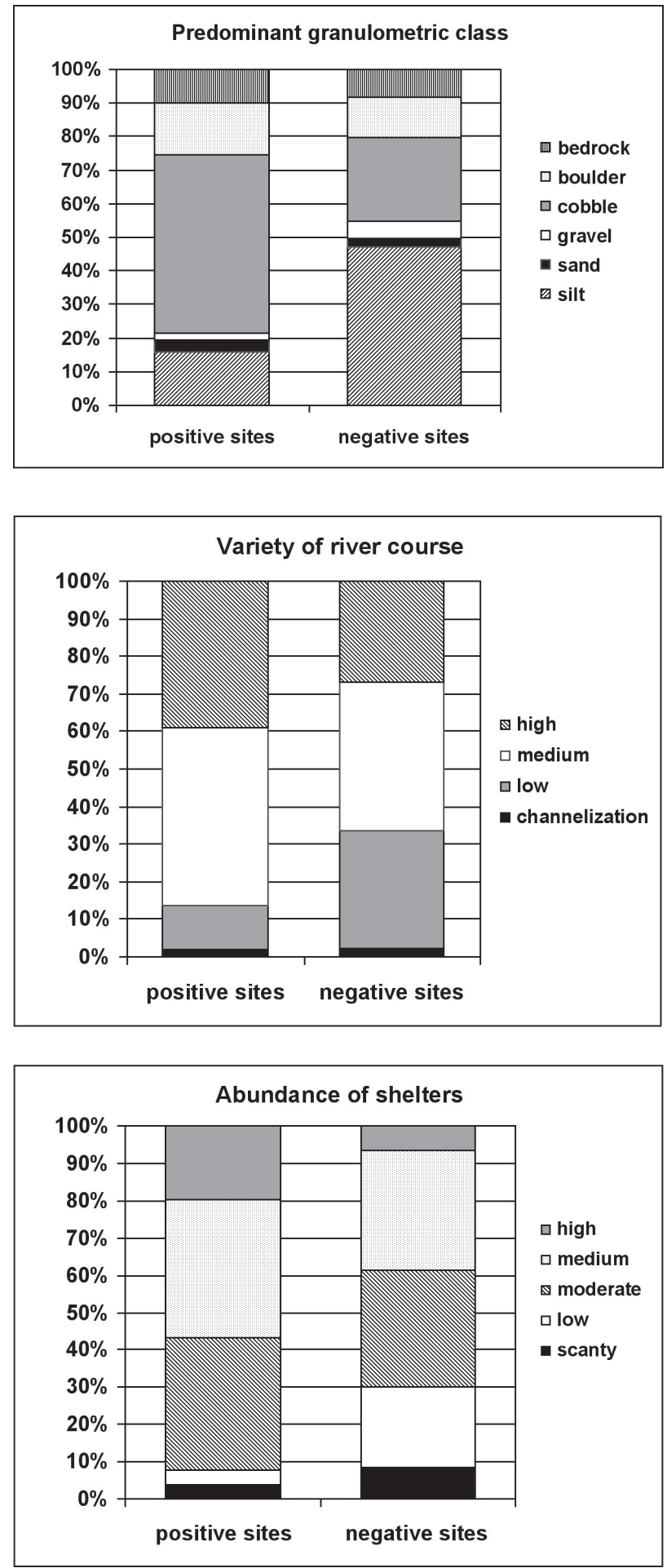

Figure 5

A. pallipes complex presence and absence according to instream habitat descriptors.

\section{Figure 5}

Caractéristiques environnementales des sites avec ou sans écrevisses. 


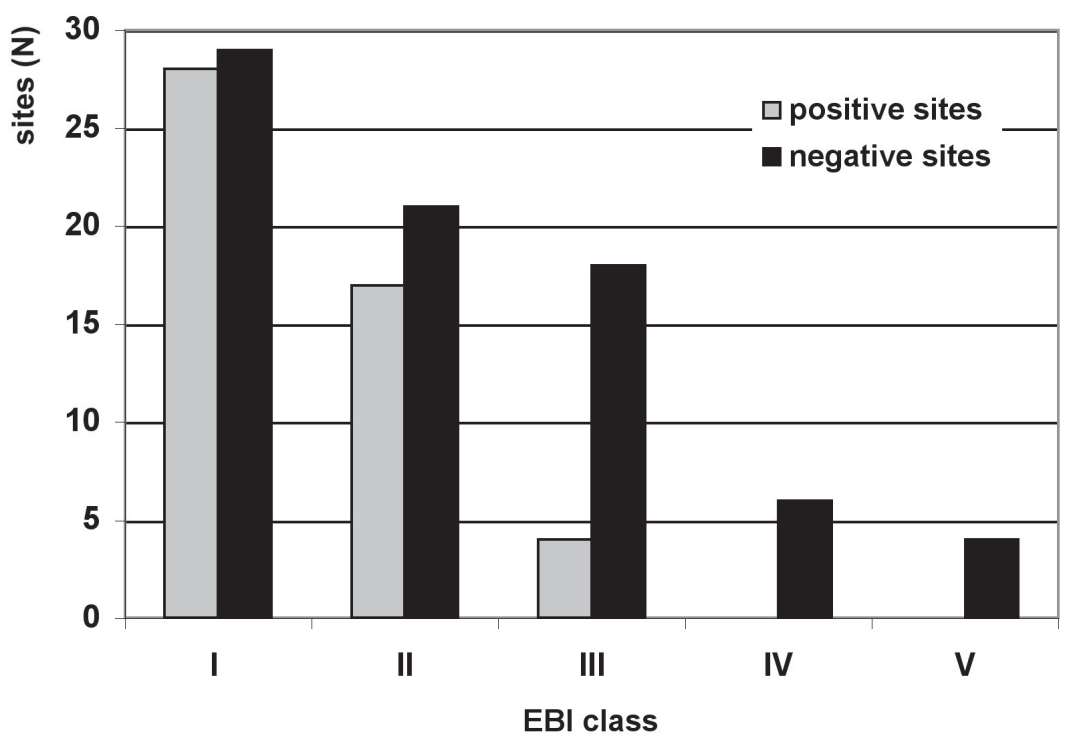

Figure 6

A. pallipes complex presence and absence according to site biological quality.

\section{Figure 6}

Niveaux de qualité biologique (classes EBI) dans les sites avec ou sans écrevisses.

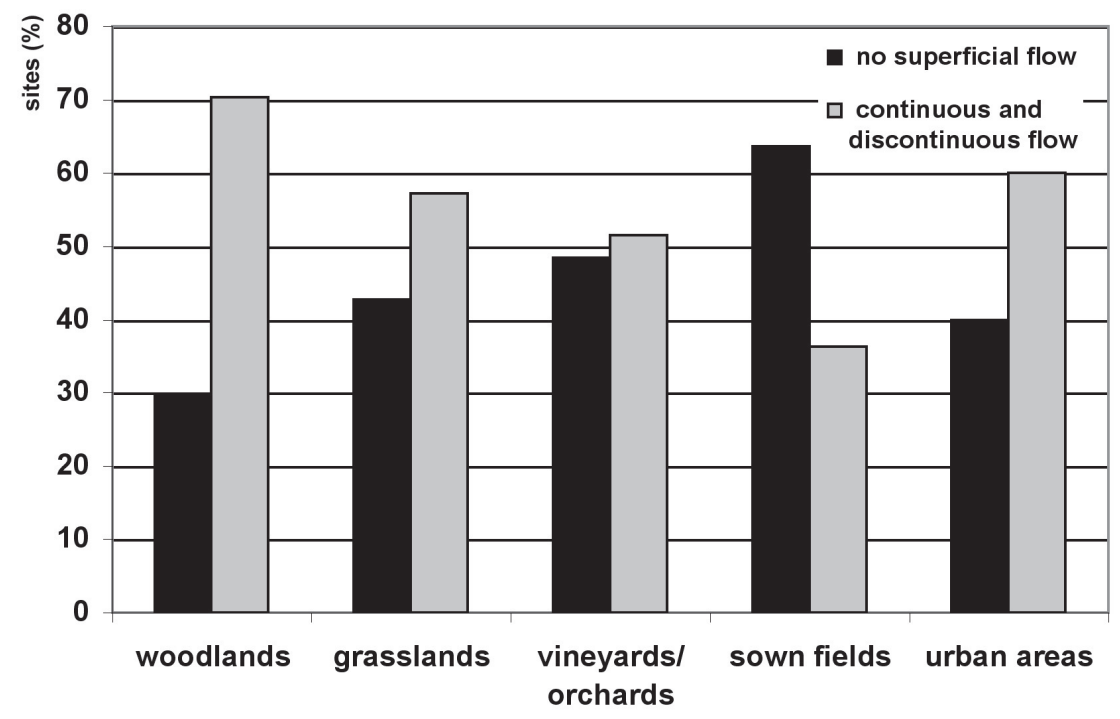

Figure 7

Presence and absence of superficial water according to land use category.

Figure 7

État hydrique des sites étudiés regroupés par catégories de mode d'utilisation du sol.

sites occupied by crayfish is much higher than the value of $607 \mu \mathrm{S} / \mathrm{cm}$ reported by RALLO and GARCIA-ARBERAS (2002), lying within the range of $457-1,638 \mu \mathrm{S} / \mathrm{cm}$ reported by ALONSO (2001). Again, RALLO and GARCIA-ARBERAS (2002) report an average water 


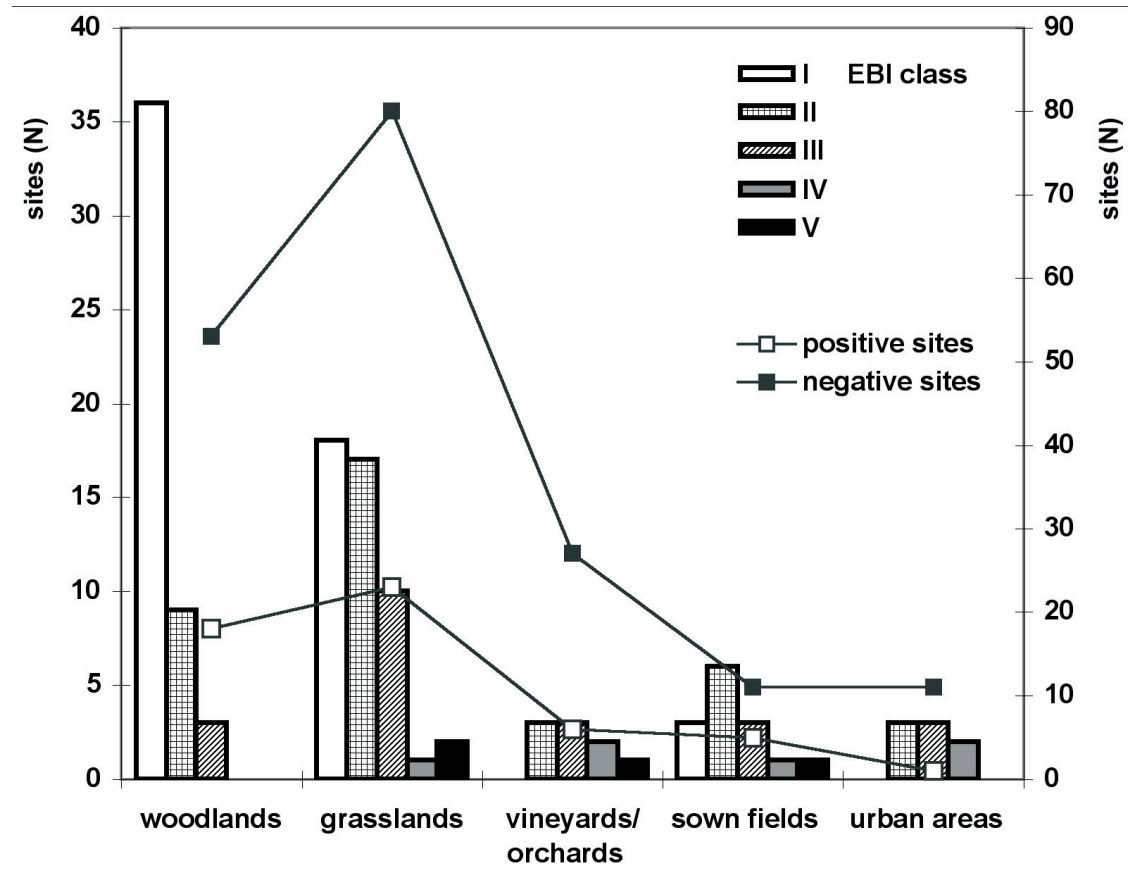

Figure 8

Bar graph: number of sites per EBI category by land use categories. Line graph: frequency of presence and absence (number of sites) of $A$. pallipes complex per land use category is shown on the secondary y-axis.

Figure 8

Niveau de qualité biologique de l'eau et présence/absence des écrevisses dans les différentes typologies d'utilisation du sol. L'axe secondaire des ordonnées (à droite) indique la fréquence ( $\mathrm{N}$ ) des sites avec ou sans écrevisses.

hardness in sites occupied by crayfish of $12.5^{\circ} \mathrm{F}$ with a maximum value of $20.4^{\circ} \mathrm{F}$, not far off the value of $22.9^{\circ} \mathrm{F}$ reported by SMITH et al. (1996). However, $90 \%$ of crayfishinhabited sites in the province of Alessandria had water hardness values of over $20.0^{\circ} \mathrm{F}$, with a maximum value of $54.5^{\circ} \mathrm{F}$ being registered. TROSCHEL (1997) reports an average dissolved $\mathrm{O}_{2}$ saturation of $85 \%$ with a minimum of $56 \%$, in this study, $24 \%$ of crayfishinhabited sites had lower dissolved oxygen saturations, with $47 \%$ being recorded for one site.

A. pallipes complex was also found to be more versatile than is usually thought in terms of the biological quality of the water. Although most populations live in sites where water quality was high (EBI classes I and II), four populations were found in sites with an EBI classification of III. These observations agree with those of the AERC (1998) and of LYONS and KELLY-QUINN (2003). The A. pallipes complex thus appears to be able to tolerate some degree of deterioration in the biological quality of the water it lives in, although populations living in such sub-optimal conditions are more vulnerable to extinction.

The statistical test results, shown in Table IV, suggest that the A. pallipes complex prefers watercourses whose natural morphology has remained intact. Human interventions like channelling and straightening of river banks reduce the habitability of the water course for $A$. pallipes complex by simplifying it and reducing the availability of microhabitats and refuges; and result in a reduction in granulometry of the bottom substrate. The degree of 
naturalness of watercourses was found to be an important requisite for crayfish, confirming findings made in France (DAGUERRE DE HUREAUX and ROQUEPLO, 1981) and in Spain (MARTÍNEZ, RICO and ALONSO, 2003).

The human impact on crayfish populations emerged clearly from the distribution pattern of crayfish-inhabited sites and human population density. Sixty-eight percent of crayfish populations were found in areas where there are no human inhabitations; and the frequency of crayfish-inhabited sites precipitated even at the lowest human population densities. Two of the effects responsible for this decline are probably a lowering of the biological quality of the water in human-inhabited areas and the availability of surface water, which is affected by land use. The high demands for water in intensive and specialized agriculture result in the drying up of watercourses in summer, when there is no rain. Forty-two and a half percent of watercourses investigated were completely dry and surface water in another $7.1 \%$ was fragmented into pools whose persistence was uncertain.

\section{CONCLUSIONS}

A substantial contraction of the distribution range of $A$. pallipes complex in the Alessandria province of Italy is indicated by the fact that only one of 18 previous reports was confirmed in this study. The present distribution pattern may be the outcome of the recently adopted practises of recalibrating watercourse sections and of dredging, and of an increase in the catchment of water sources to supply demands from new types of crop cultivation and increasing tourist urbanization in hill and mountain areas.

The results of this study on the one hand suggest that further investigation of the habitat requirements of $A$. pallipes complex is necessary, since the crayfish was absent from a large number of sites where environmental indices reflected what are thought to be favourable conditions. On the other, the A. pallipes complex appears to have a wider ecological niche than is generally thought, putting in question the meaningfulness of the bioindicators for this species.

\section{ACKNOWLEDGEMENTS}

This study was financed by the Associazione Ambiente Territorio e Formazione di Alessandria.

\section{REFERENCES}

AERC, 1998. Surveys of the distribution of freshwater crayfish (Austropotamobius pallipes) in Northern Ireland. Preparated for Environment and Heritage Service (DoE Northern Ireland), B8202, 1-76.

ALONSO F., 2001. Efficiency of electrofishing as a sampling method for freshwater crayfish populations in small creeks. Limnetica, 20, 59-72.

ANPA, 2000. I.F.F. Indice di Funzionalità Fluviale; Roma.

BARBOUR M.T., GERRITSEN J., SNYDER B.D., STRIBLING J.B., 2002. Rapid bioassessment protocols for use in streams and wadeable rivers: periphyton, benthic macroinvertebrates and fish. EPA 841-B-99-002, http://www.epa.gov/ owow/monitoring/techmon.html

BROWN D.J., BREWIS J.M., 1978. A critical look at trapping as a method of sampling a population of Austropotamobius pallipes (Lereboullet) in a mark and recapture study. Freshwater Crayfish, 4, 159-164. 
DAGUERRE DE HUREAUX N., ROQUEPLO C., 1981. Définition du biotope préférentiel de l'écrevisse à pattes blanches Austropotamobius pallipes (Ler.) dans un ruisseau landais. Bull. Fr. Pêche Piscic., 281, 211-222.

FERRARI S., 1981. Stato delle acque del Torrente Curone. Amministrazione Provinciale di Alessandria.

FONDAZIONE LOMBARDIA PER L'AMBIENTE, 2002. Applicazione dell'Indice di Funzionalità Fluviale (IFF) al sistema idrografico del Fiume Ticino. Milano.

FÜREDER L., OBERKOFLER B., HANEL R., LEITER J., THALER B., 2003. The freshwater crayfish Austropotamobius pallipes in South Tyrol: heritage species and bioindicator. In: REYNOLDS J. and SOUTY-GROSSET C., 2003: The endangered native crayfish Austropotamobius pallipes, Bioindicator and heritage species, CRAYNET, Volume 1, Bull. Fr. Pêche Piscic., 370-371, 81-95.

GHERARDI F., BALDACCINI G.N., BARBARESI S., ERCOLINI P., DE LUISE G., MAZZONI D., MORI M., 1999. Alien crayfish: the situation in Italy. In GHERARDI F. and HOLDICH D.M. (eds.), Alien Crayfish in Europe. How to Make the Best of a Bad Situation? A.A. Balkema, Rotterdam, pp. 107-128.

GHETTI P.F., 1997. Manuale di applicazione. Indice Biotico Esteso (I.B.E.). I macroinvertebrati nel controllo della qualità degli ambienti di acque correnti. Provincia Autonoma di Trento, Agenzia provinciale per la protezione dell'ambiente, Trento.

GRANDJEAN F., HARRIS D.J., SOUTY-GROSSET C., CRANDALL K.A., 2000. Systematics of the European endangered crayfish species Austropotamobius pallipes (Decapoda, Astacidae). Journal of Crustacean Biology, 20, 522-529.

IUCN, 2000. IUCN Red List of Threatened Species. Gland, Switzerland: IUCN, 2000.

LARGIADÈR C.R., HERGER M., LÖRTSCHER M., SCHOLL A., 2000. Assessment of natural and artificial propagation of the white-clawed crayfish (Austropotamobius pallipes species complex) in the Alpine region with nuclear and mitochondrial markers. Molecular Ecology, 9, 380-389.

LYONS R., KELLY-QUINN M., 2003. An investigation into the disappearance of Austropotamobius pallipes (Lereboullet) populations in the headwaters of the Nore River, Ireland, and the correlation to water quality. In: REYNOLDS J. and SOUTYGROSSET, 2003: The endangered native crayfish Austropotamobius pallipes, Bioindicator and heritage species, CRAYNET, Volume 1, Bull. Fr. Pêche Piscic., 370-371, 139-150.

MALACARNE G., CUCCO M., BOANO G., 1999. Progetto di Piano Faunistico-Venatorio della Provincia di Alessandria. Edizioni Eda, Torino.

MANCINI A., 1986. Astacicoltura. Allevamento e pesca dei gamberi d'acqua dolce. Edagricole, Bologna.

MARTÍNEZ R., RICO E., ALONSO F., 2003. Characterisation of Austropotamobius italicus (Faxon, 1914) in a central Spain area. In: REYNOLDS J. and SOUTY-GROSSET, 2003: The endangered native crayfish Austropotamobius pallipes, Bioindicator and heritage species, CRAYNET, volume 1, Bull. Fr. Pêche Piscic., 370-371, 43-56.

MORIARTY C., 1972. A study of Austropotamobius pallipes in Ireland. Freshwater Crayfish, 1, 58-67.

NASCETTI G., ANDREANI P., SANTUCCI F., IACONELLI M., BULLINI L., 1997. Struttura genetica di popolazioni italiane di gambero di fiume (Austropotamobius pallipes) e strategie per la sua conservazione. S. It. E. Atti, 18, 205-208. 
NEGRI A., CAPRì F., DONDERO F., VIARENGO A., MALACARNE G., NARDI P.A., BO T., 2003. Use of genetic markers in the endangered freshwater crayfish Austropotamobius spp. 22nd Conference of European Society for Comparative Physiology and Biochemistry (Alessandria, 14-18 Dicembre 2003).

RALLO A., GARCÍA-ARBERAS L., 2002. Differences in abiotic water conditions between fluvial reaches and crayfish fauna in some northern rivers of the Iberian Peninsula. Aquatic Living Resources, 15, 119-128.

SANTUCCI F., IACONELLI M., ANDREANI P., CIANCHI R., NASCHETTI G., BULLINI L., 1997. Allozyme diversity of European freshwater crayfish of the genus Austropotamobius. Bull. Fr. Pêche Piscic., 347, 663-676.

SMITH G.T.R., LEARNER M.A., SLATER F.M., FOSTER J., 1996. Habitat features important for the conservation of the native crayfish Austropotamobius pallipes in Britain. Biological Conservation, 75, 239-246.

SPANÒ S., REMAGGI S., 1974. Stato delle acque del Torrente Piota (Alessandria). In Atti del IV Simposio Nazionale sulla Conservazione della Natura (Bari, 23-28 Aprile 1974), 2, Istituto di Zoologia dell'Università di Bari, Bari, pp. 63-72.

TACHET H., 2002. Invertébrés d'eau douce. Systématique, biologie, écologie. CNRS Éditions, Paris.

TROSCHEL H.J., 1997. Distribution and ecology of Austropotamobius pallipes in Germany. Bull. Fr.Pêche Piscic., 347, 639-647.

ZACCARA S., STEFANI F., GALLI P., NARDI P.A., CROSA G., 2004. Taxonomic implications in conservation management of white-clawed crayfish (Austropotamobius pallipes) (Decapoda, Astacidae) in Northern Italy. Biological Conservation, 120, 1-10. 